\title{
Effects of Cooking in Solutions of Varying pH on the Dietary Fiber Components of Vegetables
}

\author{
LAURA M. BRANDT, MELISSA A. JELTEMA, MARY E. ZABIK, and BRIAN D. JELTEMA
}

\begin{abstract}
To study the effect of $\mathrm{pH}$ on dietary fiber components of vegetables, beans, cauliflower, potatoes, peas and corn were cooked in buffers of $\mathrm{pH} 2,4,6$, and 10 . Water-soluble pectin and hemicellulose, water-insoluble pectin and hemicellulose, cellulose and lignin were quantitated in raw, cooked vegetables and cooking medium. Tenderness and $\mathrm{pH}$ of raw and cooked vegetables were determined. Texture varied with cooking medium. Cooked vegetables were most firm at $\mathrm{pH} 4$ and softest at $\mathrm{pH} 10$. Dietary components found in cooking medium reflected these textural changes. Vegetables which showed greater $\mathrm{pH}$ effects exhibited greater changes in fiber components.
\end{abstract}

\section{INTRODUCTION}

A LACK OF DIETARY FIBER has been implicated in many diseases including diverticulosis, colonic cancer, constipation, and coronary heart disease (Trowell, 1976; Burkitt, 1971, 1973). A vast literature has appeared trying to substantiate or refute postulated benefits of dietary fiber. Initially it is not apparent how the lack of one dietary item could be related to such a variety of disorders. Part of this difficulty is explained by the fact that dietary fiber is not a chemical entity, but includes any type of plant material which is not digested by mammalian enzymes (i.e. cellulose, hemicellulose, lignin, pectins, gums). Since each fiber component may differ in its physiological effect, quantitative analysis of each fiber component merits investigation.

It is well known that cooking alters the textural qualities of vegetables. Many of these changes have been related to changes in the fibrous components (Campbell et al., 1979). There is also some evidence which indicates that cooking may alter the effectiveness of foods containing dietary fiber (Wyman et al., 1976). Therefore, it is important that the effect of cooking on the fiber composition of different vegetables be known, and these changes related to resulting textural changes.

Research has indicated that pectic materials decrease upon cooking due to depolymerization and solubilization (Simpson and Halliday, 1941). Cooking in salt water has been found to increase the solubility of pectin (Hughes et al., 1975). Mattheé and Appledorf (1978) analyzed several vegetables by neutral detergent fiber, acid detergent fiber, crude fiber and cellulose extraction. They, as well as others (Simpson and Halliday, 1941), found an increase in cellulose content upon cooking which they attributed to increased liberation and ease of analysis.

Van Soest (1965) suggested that heating may cause inflated lignin values due to artifacts formed by nonenzymatic browning. While high or low $\mathrm{pH}$ has been implicated in the solubilization of hemicellulose (Doesburg, 1961;

Author Zabik is affiliated with the Dept. of Food Science \& Human Nutrition, Michigan State Univ., East Lansing, MI 48824. Author Brant's current address is University Microfilm, Ann Arbor, MI. Authors M.A. and B.D. Jeltema are now affiliated with Philip Morris Research Center, Richmond, VA 23261. Inquiries should be directed to Dr. M.A. Jeltema, P.O. Box 26583, Richmond, VA 23261.
Campbell et al., 1979), pectin has been found to be susceptible to breakdown in neutral or slightly acidic $\mathrm{pH}$ ranges (Albersheim et al., 1960).

Since cooking may involve the use of solutions with varying degrees of acidity and/or alkalinity, the effects of solution $\mathrm{pH}$ on the fiber components of foods must be understood. This study was initiated to measure the effects of cooking vegetables at various pH's on the individual dietary fiber components of those vegetables using a stepwise extraction technique, and to relate these changes to the resulting textural changes.

\section{MATERIALS \& METHODS}

Vegetable preparation and cooking procedure

Common lots of fresh corn, peas, potatoes, green beans, and cauliflower were purchased from local supermarkets and prepared following typical home cooking procedures (Table 1) as recommended by Charley (1970).

The vegctables were cooked in covered $1 \frac{1}{2}$ quart Pyrcx sauccpans at medium burner setting on an electric stove in phosphate

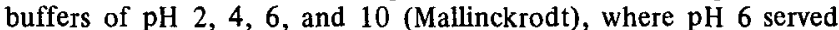
as the control. The vegetables were cooked in triplicate. Each batch cooked consisted of the five vegetables each at a different $\mathrm{pH}$ plus one vegetable in the raw state; for example, batch 1 represented: peas - raw, green beans - $\mathrm{pH} 2$, corn - $\mathrm{pH} \mathrm{4,} \mathrm{cauliflower} \mathrm{-}$ $\mathrm{pH} 6$, and potatoes - pH 10. The vegetables were cooked in this scheme until all five vegetables were prepared in all five states; thus, 25 groups of vegetables were prepared.

After cooking, each vegetable was immediately drained through a strainer into a bowl and rinsed with $60-100 \mathrm{~mL}$ of deionized water. The total volume of cooking solution was measured in a graduated cylinder and approximately $100 \mathrm{~mL}$ of it was saved for further analysis and stored at $-25^{\circ} \mathrm{C}$.

Two $50 \mathrm{~g}$ samples of each vegetable were weighed after reaching room temperature and sheared with the Allo-Kramer Shear Press, Model TR3 (Food Technology Corp. Texture-corder) at a $14 \mathrm{sec}$ downstroke. The remaining samples were cut into small pieces, frozen at $-25^{\circ} \mathrm{C}$ and lyophilized for $48 \mathrm{hr}$ in a Virtis Unitrap II freeze-drier at a pressure of 4-6 $\times 10^{-2}$ Torr and tray temperatures of $40-50^{\circ} \mathrm{C}$. Samples were then ground in a cyclone sample mill (UD Corp., Boulder, CO) and stored in polyethylene sample bags in a desiccator containing Drierite $\left(\mathrm{CaSO}_{4}\right)$.

Table 1-Preparation and cooking methods for fresh vegetable (200g lots)

\begin{tabular}{llcc}
\hline Vegetabie & $\begin{array}{c}\text { Preparation } \\
\text { method }\end{array}$ & $\begin{array}{c}\text { Cooking solution } \\
\text { before cooking } \\
(\mathrm{mL} \text { buffer })\end{array}$ & $\begin{array}{c}\text { Cooking } \\
\text { time } \\
(\mathrm{min})\end{array}$ \\
\hline Potatoes & $\begin{array}{l}\text { Peeled, cut } \\
\text { into 1 inch } \\
\text { cubes }\end{array}$ & 350 & 10 \\
Green Beans & $\begin{array}{l}\text { Cut into 1 } \\
\text { inch pieces }\end{array}$ & 250 & 11 \\
$\begin{array}{l}\text { Peas } \\
\text { Corn } \\
\text { Caulifiower }\end{array}$ & $\begin{array}{l}\text { Cut off cob } \\
\text { Cut into 1X11/2 } \\
\text { inch cubes }\end{array}$ & 200 & 12 \\
\hline
\end{tabular}

Time to reach fork tender stage. 


\section{Proximate analyses}

The moisture content of each raw and cooked vegetable was determined by AACC procedure 44-40 (AACC, 1962) using 2-g duplicate samples of each vegetable which were dried at $90^{\circ} \mathrm{C}$ under a vacuum.

The raw, freeze-dried vegetables were analyzed for crude fat, crude protein, and ash. Crude fat was determined by using approximately 3.0-g samples in a Soxhlet apparatus with hexanes as the extractant, a revision of AACC method 30-25 (AACC, 1962). Crude protein was determined by a revision of AACC method 46-13 (AACC, 1962) using a micro-Kjeldahl apparatus and an approximately $30 \mathrm{mg}$ sample. Approximately $0.5 \mathrm{-g}$ samples were ashed at $525^{\circ} \mathrm{C}$ for $48 \mathrm{hr}$, a revision of AACC method 08-01 (AACC, 1962).

\section{Fiber extraction}

All samples were analyzed according to the same scheme as described for cooking; however, 10 samples were analyzed at one time, i.e., two groups of vegetables. This was done according to a confounding plan in which a portion of the two factor interaction was confounded. The extraction procedure used is essentially the same as explained by Jeltema and Zabik (1980), with minor modifications. The scheme and modifications are shown in Fig. 1. As indicated by Jeltema and Zabik (1980), colorimetric analyses were made to separately determine hexose, pentose, and uronic acid composition of each fraction. The pentose content of all insoluble fractions (i.e. starch, protein, pectin, cellulose, and insoluble hemicellulose) was combined to yield total insoluble hemicellulose. Insoluble pectin was taken as a combination of uronic acids present in the starch and pectin fraction. Soluble material extracted from the vegetable was divided into pentoses (soluble hemicellulose) and uronic acids (soluble pectin). Material extracted into the cooking media (pentoses and uronic acids) were termed cooking solution fiber.

\section{$0.2 \mathrm{~g}$ dry sample}

Chlorophyll extraction ${ }^{a}$

(Ethyl ether: beans and peas only)

Total Water Solubles

(Water, room temp:

two 2-hr extractions)<smiles>CCC</smiles>

Starch Extraction

(Amyloglucosidase, $37^{\circ} \mathrm{C} / 18 \mathrm{hr}$,

$2 \mathrm{M}$ acetate buffer @ $\mathrm{pH} 4.5)$

$$
\text { I }
$$

Protein Extraction

(Pepsin, $37^{\circ} \mathrm{C} / 20 \mathrm{hr}$.

$1: 1$ water $/ 0.2 \mathrm{~N} \mathrm{HCl}$

$$
1
$$

Pectin Extraction

(Sequester divalent ions w/EDTA;

demethylate $\mathrm{pH} 11.5 \rightarrow 5.5$;

Pectinase, room temp $/ 1 \mathrm{hr}$

$$
\text { I }
$$

Water Insoluble Hemicellulose

$15 \% \mathrm{v} / \mathrm{v} \mathrm{H}_{2} \mathrm{SO}_{4}$, three 1-min ex-

tractions, temp below $100^{\circ} \mathrm{C}$

Cellulose

$172 \%$ w/ $\mathrm{w} \mathrm{H}_{2} \mathrm{SO}_{4}$

$48 \mathrm{hr} / 2.4^{\circ} \mathrm{C}$

Lignin

(Wt after cellulose -

wt after ashing)

Fig. 1-Extraction scheme for fiber components. "Chlorophyll was removed from beans and peas to avoid colorimetric interfer. ences. $3 \times 50 \mathrm{~mL}$ on fritted glass Gooch crucibles.
Water Soluble Hemiextraction with amyloglucosidase; dialysis)

\section{Statistical analyses}

Orthogonal comparisons were made for differences due to cooking, differences among the five vegetables themselves, and differences due to media $\mathrm{pH}$, divided into linear, quadratic, and cubic effects. The data were analyzed to determine whether the vegetables reacted the same to media $\mathrm{pH}$ (media $\mathrm{pH} \times$ vegetable). Each vegetable was analyzed for the effect of cooking, which was divided into linear, quadratic, and cubic effects. These analyses were calculated for hexose, pentose, and uronic components in each fraction as well as the total of these components. The LSSTEP statistical program was run on a CDC 6500 computer to obtain prediction equations for shear, where fiber components were used as the independent variables.

\section{RESULTS \& DISCUSSION}

Shear

Fig. 2 shows a plot of the force to shear versus pH of the five vegetables. In the raw state, the firmness was found to decrease in the following order: cauliflower, beans, potatoes, peas, and corn. All of the vegetables were firmest at $\mathrm{pH} 4$ in the cooked state. In general, the vegetables were softest at $\mathrm{pH} \mathrm{10;} \mathrm{at} \mathrm{pH} 2$, the firmness was only surpassed hy the results of $\mathrm{pH} 4$. These results agree favorably with those of Doesburg (1961) who showed that plant tissues possess maximum firmness at $\mathrm{pH} 4.0-4.5$. He observed decreased firmness at $\mathrm{pH}$ values both higher and lower than $\mathrm{pH}$ 4. The reasons behind these phenomena and their relation to fiber components will be discussed further.

Statistical analyses of the shear data are shown in Table 2 . In general, the vegetables were affected by cooking and $\mathrm{pH}$. The vegetables did not react the same to media $\mathrm{pH}$, as reflected by the significance of media $\mathrm{pH} \times$ vegetable interaction.

Beans and cauliflower showed the most dramatic changes due to cooking media. They exhibited significant linear effects since their firmness decreased as $\mathrm{pH}$ increased. They showed significant quadratic and cubic effects since at $\mathrm{pH}$ celluloses (Starch

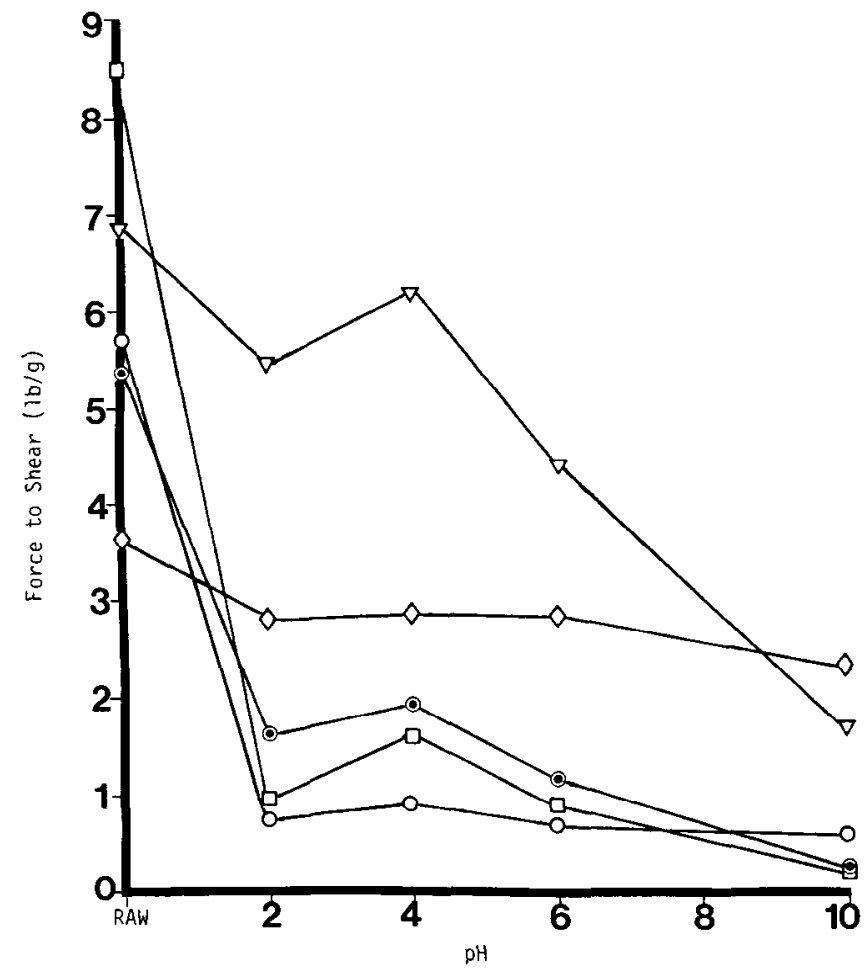

Fig. 2-Plot of force to shear vs $\mathrm{pH}$ for potatoes, $0-0 ;$ cauliflower

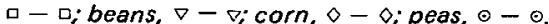


4 they were firmer than either pH 2 or 6 . Peas showed similar effects. Corn and polatoes showed no significant effects, except in comparing the raw and cooked vegetables.

\section{Cooking solution}

The cooking solution fiber represents the material extracted into the cooking media, plotted in Fig. 3. In general, the most cooking solution fiber was extracted at $\mathrm{pH} 10$, the lowest amount at $\mathrm{pH} 4$. Those vegetables which showed the largest changes in shear values upon cooking also showed the greatest amount of material extracted into the cooking media. Cauliflower and peas showed the most material extracted into the cooking media, followed by beans, potatoes, and corn. Corn showed very little material extracted at all $\mathrm{pH}$ levels, which relates well to the shear data, also showing little change with $\mathrm{pH}$ cooking.

While the trends seen between vegetables should be similar, the precise effect of the $\mathrm{pH}$ on the vegetable will be modified by the concentrations of the components in the raw state, length of cooking, size and shape of the food, and ease of sulvent penetration.

For example, corn which contains little total fiber (Table 3) was relatively unaffected by any cooking procedure. However, cauliflower, beans, and peas which generally contained higher concentrations of pectin and hemicellulose were not affected equally by cooking. Peas and beans, which are more difficult to penetrate, were generally less affected than cauliflower. Potatoes which are much higher in starch than any of the other vegetables were more affected by cooking, which causes starch gelatinization, than by $\mathrm{pH}$.

Upon comparing the individual pentose values and uronic acid values comprising cooking solution fiber, the uronic components outweighed the pentose components for all vegetables at all $\mathrm{pH}$ levels, except for corn. The trends for the pentose fractions were similar in all vegetables. The amount of soluble hemicellulose did not vary

Table 2-Significance levels of orthogonal comparisons for cooking solution fiber, water soluble fiber components, and shear

\begin{tabular}{|c|c|c|c|}
\hline Vegetable & $\begin{array}{l}\text { Cooking } \\
\text { solution } \\
\text { fiber }\end{array}$ & $\begin{array}{l}\text { Water soluble } \\
\text { hemicellulose }\end{array}$ & Shear \\
\hline \multicolumn{4}{|l|}{ Peas } \\
\hline Raw vs cooked & ** & & ** \\
\hline Linear & ** & & ** \\
\hline $\begin{array}{l}\text { Quadratic } \\
\text { Cubic }\end{array}$ & $* *$ & * & * \\
\hline \multicolumn{4}{|l|}{ Corn } \\
\hline Raw vs cooked & & & ** \\
\hline Linear & & & \\
\hline Quadratic & & & \\
\hline Cubic & & & \\
\hline \multicolumn{4}{|l|}{ Potatoes } \\
\hline Raw vs cooked & ** & * & $* *$ \\
\hline Linear & ** & & \\
\hline Quadratic & $*$ & & \\
\hline Cubic & & & \\
\hline \multicolumn{4}{|l|}{ Beans } \\
\hline haw vs cooked & $*$ & $* *$ & ** \\
\hline Linear & ** & ** & ** \\
\hline Quadratic & ** & & ** \\
\hline Cubic & & & $* *$ \\
\hline \multicolumn{4}{|l|}{ Cauliflower } \\
\hline Raw vs cooked & ** & ** & ** \\
\hline Linear & ** & ** & ** \\
\hline Quadratic & ** & ** & * \\
\hline Cubic & & & * \\
\hline
\end{tabular}

$\star p<0.05$

$* * p<0.01$ significantly in pH levels 2,4 , and 6 ; however, a distinct increase was exhibited from these three pH levels to $\mathrm{pH} 10$. In general, the uronics showed small increases in soluble pectin from $\mathrm{pH} 2$ to $\mathrm{pH} 6$, with a much more rapid increase up to $\mathrm{pH} 10$. Because of these trends, all vegetables except corn showed significant linear and quadratic effects (Table 2 ). These results agree with the work of Doesburg (1961) and Selvendran et al. (1979).

\section{Water soluble fiber}

The solubilization of fiber components during cooking was also seen in the concentrations of soluble hemicellulose and pectin remaining in the vegetables. Both tended to increase with pH (Fig. 4 and 5; Table 2) with the most dramatic effects seen again at $\mathrm{pH} 10$. These results agree with those found by other researchers (Doesburg, 1961; Van Soest and Robertson, 1977). These researchers also found an increase of soluble hemicellulose in acidic media. Most of the vegetables showed some increase in solubilization at $\mathrm{pH} 2$ either in water-soluble hemicellulose or soluble pectin. The extent of this solubilization again depended on the vegetable. This increased solubilization at $\mathrm{pH} 2$ was noticed in the shear data where most of the vegetables were slightly less firm than at $\mathrm{pH} 4$. Corn, however, again showed no change in shear or solubilization due to $\mathrm{pH}$.

Table 3-Proximate analysis of vegetables ${ }^{a}$

\begin{tabular}{lrrrrrr}
\hline Vegetable & $\begin{array}{c}\text { \% Crude } \\
\text { protein }\end{array}$ & $\begin{array}{c}\% \text { Crude } \\
\text { fat }^{c}\end{array}$ & $\begin{array}{c}\% \\
\text { Ash }\end{array}$ & $\begin{array}{c}\% \\
\text { Starch }\end{array}$ & $\begin{array}{c}\% \\
\text { Fiber de }\end{array}$ & $\begin{array}{r}\% \text { Re- } \\
\text { covery df }\end{array}$ \\
\hline Peas & 30.2 & 0.9 & 4.2 & 12.0 & 14.6 & 90 \\
Beans & 19.0 & 0.8 & 7.4 & 2.8 & 18.9 & 93 \\
Corn & 12.7 & 3.5 & 3.5 & 18.2 & 8.0 & 102 \\
Potatoes & 10.9 & 0.2 & 5.6 & 51.6 & 11.6 & 94 \\
Cauliflowor & 25.3 & 1.1 & 7.6 & 1.5 & 17.3 & 93 \\
\hline
\end{tabular}

a Reported on a dry basis

bean based on 3 replications ( $N \times 6.25$ crude protein)

c Mean based on 2 replications

Mean based on average of 15 analyses ( 3 replicates $\times 5$ analyses)

Sum of water soluble pentose and uronic: cellulose hexose; lignin; pectin - uronics from starch and pectín; hemicellulose - pentoses of starcn, protein, pectin, hemicellulose; cellulose

$f$ Sum of hexoses, pentoses, and uronic acids from each extraction step; protein; fat; ash; starch

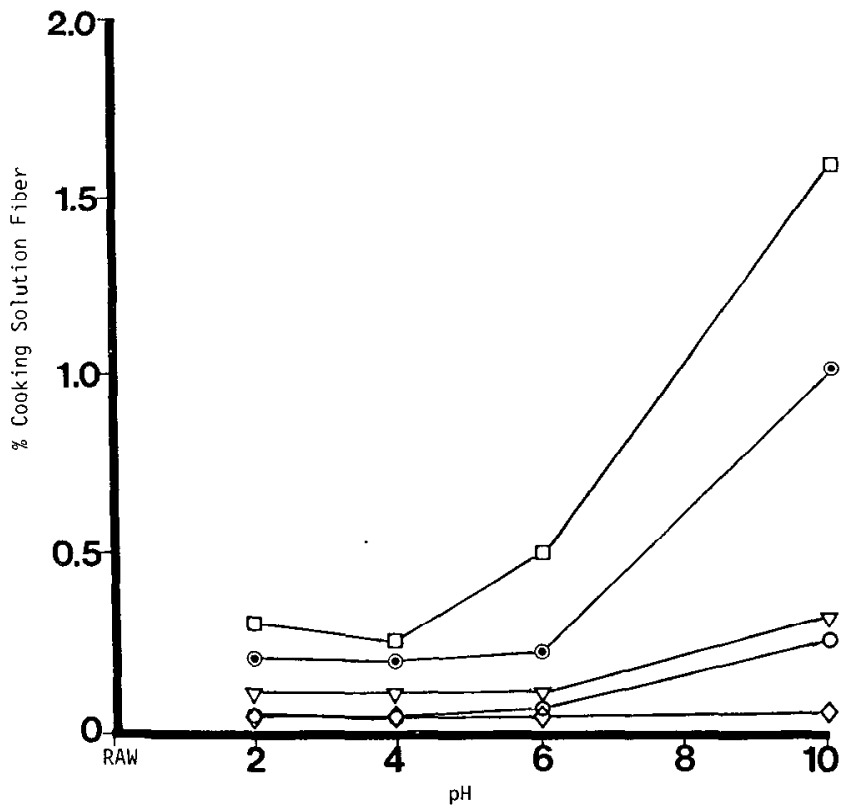

Fig. 3-Percent cooking solution fiber vs $\mathrm{pH}$ for potatoes, cauliflower, beans, corn, and peas. (Symbols same as Fig. 2). 


\section{Pectin}

Pectin is usually thought to be stable in acid and unstable in alkali (Kertesz, 1951). As noted earlier some increased solubilization was noted in this study at very low $\mathrm{pH}$. The greater instability of the vegetables to alkali was shown by the dramatic decrease seen in some vegetables at pH 10 (Table 4).

Doesburg (1961) demonstrated that at $\mathrm{pH} \mathrm{4,} \mathrm{hardness-}$ meter readings correlated directly with the amount of pectin in vegetables. While these trends were demonstrated by the amount of uronic material in the cooking solution and soluble uronic material remaining in the vegetables, these trends were not always seen in the insoluble-pectic fraction. The water-insoluble fraction should show inverse trends to those seen by the water soluble fraction. While this was seen in the alkaline side, the trends were not opposite under acidic conditions. Proceeding from raw through $\mathrm{pH} 6$, one would expect to see highest levels of pectin in the raw with an upward trend at $\mathrm{pH}$ 4. The reasons for this discrepancy are not known, although ease of hydrolysis and analysis may be affected by $\mathrm{pH}$. Also, the data used for insoluble pectin were taken by adding the uronic data from several fractions. The uronics extracted in the starch step was often as large as that remaining in the vegetable. This nonselective extraction added to analysis difficulties and points out the need for more selective extraction enzymes or procedures.

\section{Water insoluble hemicellulose}

Corn and potatoes displayed no significant changes in water-insoluble hemicellulose from $\mathrm{pH} 2$ to $\mathrm{pH} 10$, which is consistent with the shear data (Table 4). More obvious changes were evident in cauliflower ( $p<0.01$, linear), beans, ( $p<0.05$, linear), and peas, each showing a de-

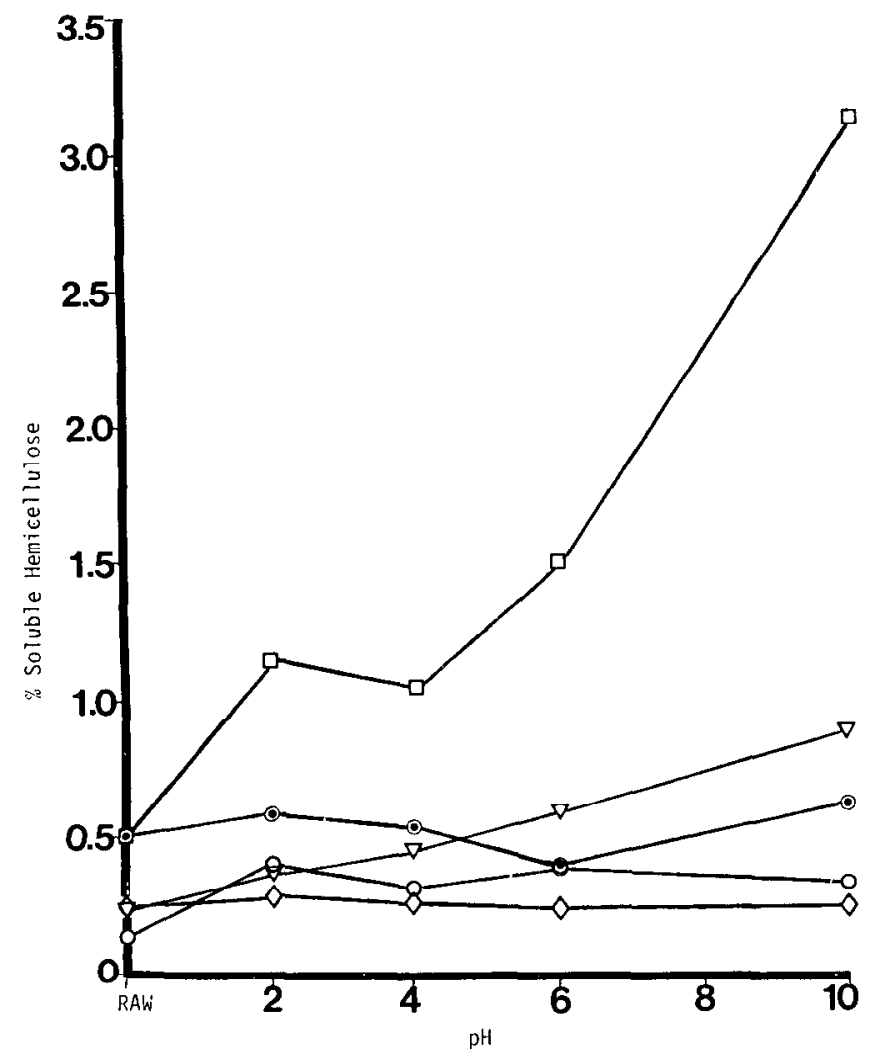

Fig. 4-Percent soluble hemicellulose vs $\mathrm{pH}$ for potatoes, cauliflower, beans, corn, and peas. (Symbols same as Fig. 2). crease from $\mathrm{pH} 6$ to $\mathrm{pH} 10$. This phenomenon correlates well with the shear data, which shows a decrease in firmness at basic $\mathrm{pH}$.

Van Soest and Robertson (1977) and Heller et al. (1977) found that most plant tissues show increased soluble hemicellulose at both high and low $\mathrm{pH}$ values; at neutral $\mathrm{pH}$, hemicellulose is the least soluble. This is the basis for the detergent fiber method. However, the vegetables did not demonstrate a decrease in hemicellulose under acidic conditions, except in cauliflower $(p<0.05$, quadratic).

Since the insoluble-hemicellulose values were comprised of five fractions, perhaps all of the fractions do not contain true hemicellulose. For example, the starch pentoses were solely arabinose as indicated by the HPLC results, which may stem from either hemicellulose or pectin. Both protein and pectin pentoses were mainly xylose, but also contained arabinose. The opposite was true for insoluble-hemicellulose pentoses. This demonstrates the problem of correctly attributing each fraction to one specific fiber component.

\section{Cellulose}

The cellulose values are plotted in Table 4 . The only significant $(p<0.01)$ term was the "Vegetable" component which means that there were differences among the five vegetables themselves.

The increased cellulose values obtained by Simpson and Halliday (1941), Mattheé and Appledorf (1978), and Herranz et al. (1981), explained by increased hydrolysis and liberation of the material were not congruent with the data presented in this study. The data showed no significant changes in cellulose with cooking which correlated with the strongly acidic conditions needed to degrade cellulose. This

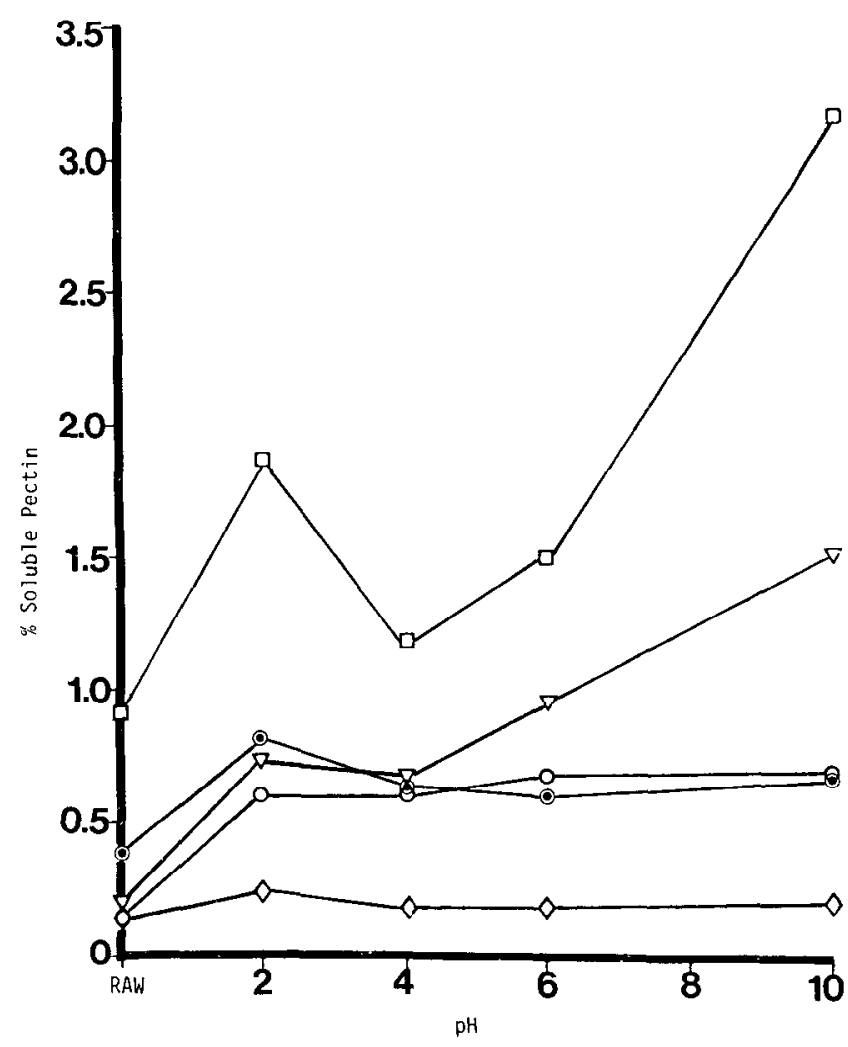

Fig. 5-Percent soluble pectin vs pH for potatoes, cauliflower, beans, corn, and peas. (Symbols same as Fig. 2). 
DIETARY FIBER COMPONENTS OF VEGETABLES...

Table 4-Percent of insoluble pectin, insoluble hemicellulose, cellulose, and lignin remaining in the vegetables

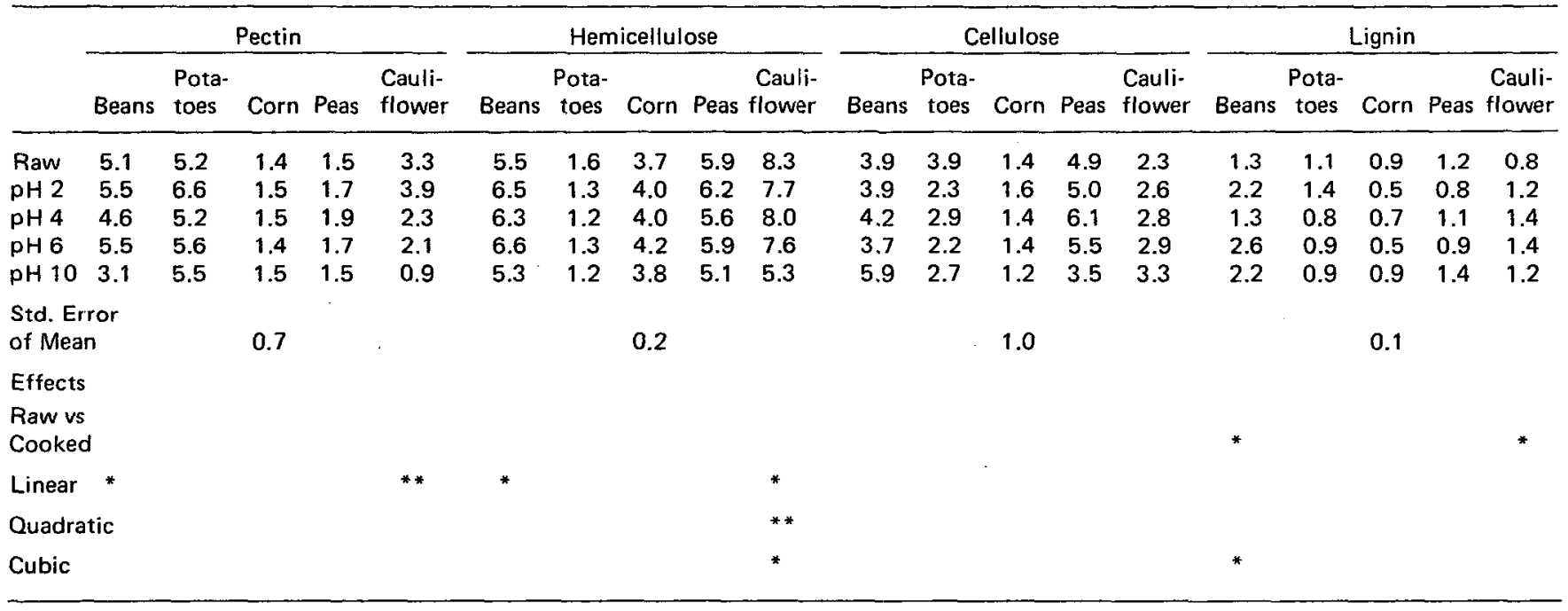

* $p<0.05 ; \quad * * p<0.01$

agrees with the findings of Day (1909), Sterling (1955), and Sterling and Bettelheim (1955).

\section{Lignin}

Lignin, the material remaining after a 48-hr extraction with cold $72 \%$ sulfuric acid, is shown in Table 4 . Beans $(p<0.01)$ and cauliflower $(p<0.05$ displayed significantly greater lignin in the cooked vegetables compared to the raw. This agrees with the studies of Matthee and Appledorf (1978), who attributed lignin increases mainly to tannin-protein condensation products during cooking as postulated by Van Soest (1965). Beans also showed a significant $(\mathrm{p}<0.01)$ cubic relationship as a result of the increased levels of lignin at $\mathrm{pH} 2$ and $\mathrm{pH} 6$, and the decrease at $\mathrm{pH} 4$. No other $\mathrm{pH}$ effects on lignin were noted.

\section{Proximate analysis}

Table 3 shows the results of crude protein, crude fat, starch, and ash determinations on the vegetables reported on a dry basis. Also shown are total calculated fiber and average percent recoveries. Total fiber values are probably lower than actual since components analyzed in some steps were not added to any fraction due to problems in identifying to which fraction they belonged. These were primarily hexose sugars (Jeltema and Zabik, 1980).

\section{Relationship between fiber components and shear force}

A few significant simple correlations were evident between fiber components and shear force as shown in Table 5. The two major components that correlated with shear were insoluble pectin and water-soluble hemicellulose.

Pectin was correlated most positively with shear $(\mathrm{p}<$ 0.01 ), followed by the pectin pentoses. The pentoses and uronics of soluble hemicellulose were negatively correlated with shear $(\mathrm{p}<0.05)$, as well as the sum of the soluble hemicelluloses. This agrees with the findings of Doesburg (1961) and Reeve (1970) who agreed that changes in pectin influence texture in plants. Lignin showed a positive correlation with shear, although not significant. However, the pectin $x$ lignin interaction was significant at $p<0.05$. These findings indicate that both pectin and lignin contribute to increased firmness in vegetables. Other terms involving pectin were highly significant such as pectin squared, cellulose $x$ pectin, and pectin $\times$ hemicellulose.
Table 5-Simple correlations of fiber components with shear force

\begin{tabular}{lc}
\hline Component & Shear \\
\hline Pectin & $0.61^{* *}$ \\
Water-Soluble Hemicellulose & $-0.37^{*}$ \\
Water-Soluble Pectin & $-0.37^{*}$ \\
Water-Soluble Fiber ( $\Sigma$ hexose, pentose, uronic) & $-0.35^{*}$ \\
Pectin Pentoses & $0.56^{* *}$ \\
Pectin Sq & $0.59^{* *}$ \\
Cellulose $\times$ Pectin & $0.54^{* *}$ \\
Pectin $\times$ Lignin & $0.44^{*}$ \\
Pectin $\times$ Hemicellulose & $0.53^{* *}$ \\
Water-Soluble Fiber $\times$ Hemicellulose & $-0.44^{*}$ \\
\hline
\end{tabular}

$* p<0.05$

$\star * p<0.01$

It is well known that the loss of hemicelluloses contribute to the softening of vegetables. This was reflected by the negative correlations found in all terms involving water-soluble hemicellulose.

The prediction equation, calculated by using fiber components as the independent variables, showed that shear can be predicted for vegetables cooked at different $\mathrm{pH}$ values by insoluble pectin, lignin, and water-soluble fiber (sum of hexoses, pentoses and uronics):

Shear $=1.52$ Pectin -2.60 Lignin $-0.37 \Sigma$ Soluble Fiber

The regression coefficient shows how well the equation predicted shear. Since $\mathrm{R}^{2}=0.66,66 \%$ of the variation in tenderness can be predicted by this equation. The above equation included both raw and cooked vegetables. When only the raw vegetables were included in the equation, the regression coefficient increased to 0.87 , indicating that $87 \%$ of the variation in tenderness could be predicted in the raw vegetables, only pectin and the total water-soluble hemicelluloses figuring into the equation. The lignin values were too similar in the raw vegetables and consequently were not included in the prediction equation:

Shear $=0.70$ Pectin $+1.68 \Sigma$ Soluble Fiber +2.80 .

\section{REFERENCES}

Albersheim, P., Neukom, H., and Deuel, H. 1960. Splitting of pectin chain molecules in neutral solutions. Arch. Biochem. Biophys. 90: 46.

American Association of Cereal Chemists. 1962. "AACC Approved Methods," 7 th ed. The Association. St. Paul, MN.

Burkitt, D.P. 1971. Epidemiology of cancer of the colon and recBurkitt, D.P. 1971. Epidemiology of cancer of the colon and rec-
tum. Cancer 28: 3 . 